\title{
PENERAPAN METODE K-MEDOIDS CLUSTERING PADA PENANGANAN KASUS DIARE DI INDONESIA
}

\author{
Fitri Hardiyanti ${ }^{1}$, Heru Satria Tambunan ${ }^{2}$, Ilham Syaputra Saragih ${ }^{3}$ \\ ${ }^{123}$ Program Studi Sistem Informasi, STIKOM Tunas Bangsa Pematangsiantar \\ Email: ${ }^{1}$ fitrihardianti5678@ gmail.com, ${ }^{2}$ heru@amiktunasbangsa.ac.id, ${ }^{3}$ ilhamsyahputrasaragih@gmail.com
}

\begin{abstract}
Abstrak
Diare adalah kondisi di mana seseorang buang air besar dalam bentuk encer atau cair dan terjadi berulang kali. Diare dapat menyebabkan hilangnya sejumlah besar air dan zat-zat yang dibutuhkan tubuh.. Penyakit diare merupakan salah satu masalah kesehatan di negara berkembang, terutama di Indonesia baik di perkotaan maupun di pedesaan. Angka penyakit diare sekitar 200400 kejadian di antara 1000 penduduk setiap tahunnya. Dengan demikian di Indonesia dapat ditemukan sekitar 60 juta kejadian setiap tahunnya, sebagian besar (70-80\%) dari penderita ini adalah anak di bawah lima tahun (BALITA). Sebagian dari penderita (1- 2\%) akan jatuh ke dalam dehidrasi dan kalau tidak segera ditolong 50-60\% di antaranya dapat meninggal. Kelompok ini setiap tahunnya mengalami kejadian lebih dari satu kejadian diare. Algoritma K-Medoids Clustering adalah salah satu algoritma yang digunakan untuk mengelompokan data.
\end{abstract}

Kata kunci: Data Mining, K-Medoids, Clustering, Diare

\begin{abstract}
Diarrhea is a condition in which a person defecates in a runny or liquid form and occurs repeatedly. Diarrhea can cause the loss of large amounts of water and substances needed by the body. Diarrhea is one of the health problems in developing countries, especially in Indonesia both in urban and rural areas. Diarrhea morbidity rates around 200-400 occurrences among 1000 residents each year. Thus in Indonesia there can be around 60 million incidents each year, most (70-80\%) of these sufferers are children under five years (BALITA). Some patients (1-2\%) will fall into dehydration and if not immediately helped 50-60\% of them can die. This group experiences more than one incidence of diarrhea every year. K-Medoids Algorithm Clustering is one of the algorithms used for to group data.
\end{abstract}

Keywords: Data Mining, K-Medoids, Clustering, Diarrhea

\section{PENDAHULUAN}

Diare merupakan penyakit yang tidak asing terdengar dikalangan masyarakat. Penyakit ini bisa terjadi kapan saja dan pada siapa saja, mulai dari kalangan anak-anak sampai kalangan dewasa. Diare dalam bahasa Indonesia biasa disebut dengan "buang air besar" atau diarrhea dalam bahasa Inggris. Diare merupakan sebuah gangguan pada saluran pencernaan dimana tinja atau feses berubah menjadi cair dan terjadi 3-7 kali dalam waktu 24 jam. Penyakit ini biasanya disertai dengan sakit perut, rasa mulas yang berkepanjangan, dehidrasi dan sering mual serta muntah. Penyakit ini disebabkan dari pola konsumsi makanan yang terkontaminasi oleh beberapa bakteri, virus dan parasit yang muncul di tempat yang kurang bersih. Sudah sewajarnya kebersihan lingkungan dan makanan menjadi perhatian utama bagi para orang tua, agar anak terhindar dari penderitaan diare. Berdasarkan riset yang dilakukan oleh Departmen Kesehatan Republik Indonesia pada tahun 2007, diare dikategorikan sebagai penyakit yang menyebabkan kematian pada semua usia. Sedangkan sebagai peringkat penyakit menular, diare menempati peringkat ketiga yang menyebabkan seseorang meninggal dibandingkan dengan TBC dan Pneumonia. Di Indonesia penyakit diare ini menjadi salah satu masalah kesehatan terbesar dimata masyarakat. Oleh karena itu, perlu adanya suatu sistem untuk mengelompokkan provinsi di Indonesia menjadi dua cluster yaitu cluster tinggi dan cluster rendah, dimana provinsi yang masuk ke dalam cluster tinggi menjadi pusat perhatian bagi pemerintah dalam menanggulangi penyakit tersebut.Data mining berkaitan dengan bidang ilmu - ilmu lain, seperti database system, data warehousing, statistik, machine learning, information retrieval, dan komputasi tingkat tinggi. Selain itu, data mining didukung oleh ilmu lain seperti neural network, pengenalan pola, spatial data analysis, image database, signal processing [1].

Algoritma PAM sering dikenal dengan algoritma K-Medoids merupakan sebuah algoritma yang merepresentasikan cluster yang dibentuk menggunakan medoids. Proses pembentukan cluster dimulai dengan menentukan k objek dari dataset secara acak sebagai medoid, selanjutnya hitung cost setiap objek non-medoid dengan $\mathrm{k}$ objek, cost terkecil setiap objek non-medoid terhadap medoid akan masuk dalam cluster dimana medoid tersebut berada [2].

\section{TEORITIS}

\subsection{Data Mining}

Menurut Gambbeta Windy (2012) dikutip oleh [3] secara sederhana, data mining dapat diartikan sebagai proses seleksi, eksplorasi, dan pemodelan dari sejumlah besar data untuk menemukan pola atau kecenderungan yang biasanya tidak disadari keberadaannya. Data mining dapat dikatakan sebagai proses mengekstrak pengetahuan dari sejumlah besar data yang tersedia. Pengetahuan yang dihasilkan dari proses data mining harus baru, mudah 
dimengerti, dan bermanfaat. Data mining merupakan sebuah inti dari proses KDD, meliputi dugaan algoritma yang mengeksplor data, membangun model dan menemukan pola yang belum diketahui. KDD bersifat otomatis, dapat diartikan sebagai pengorganisasian proses untuk pengidentifikasian yang benar, berguna dan penemuan pola dari kumpulan data yang besar dan komplek [4].

\subsection{Clustering}

Menurut Larose (2015) dikutip oleh [5] Clustering merupakan suatu proses pengelompokkan record, observasi, atau mengelompokkan kelas yang memiliki kesamaan objek. Perbedaan clustering dengan klasifikasi yaitu tidak adanya variabel target dalam melakukan pengelompokan pada proses clustering. Clustering sering dilakukan sebagai langkah awal dalam proses data mining.

\subsection{Algoritma $K$-Medoids}

Menurut [6] Algoritma Partition Around Medoids (PAM) atau dikenal juga dengan K-medoids dikembangkan oleh Leonard Kaufman dan Peter J. Rousseeuw pada tahun 1987. Algoritma PAM termasuk metode partitioning clustering untuk mengelompokkan sekumpulan $\mathrm{n}$ objek menjadi sekumpulan k cluster. Representasi cluster pada PAM adalah objek dari sekumpulan objek yang mewakili cluster, disebut medoid. Beberapa langkah-langkah dalam perhitungan algoritma K-Medoids sebagai berikut :

1. Inisialisasi pusat cluster sebanyak k (jumlah cluster)

2. Alokasikan setiap data (objek) ke cluster terdekat menggunakan persamaan ukuran jarak Euclidian Distance dengan persamaan:

$d_{e u c}\left(x_{i j}, c_{k j}\right)=\sqrt{\sum_{j=1}^{p} \sum_{i=1}^{n}\left(x_{i j}-c_{k j}\right)^{2}}$

Dimana:

$\mathrm{d}_{\mathrm{euc}}\left(\mathrm{x}_{\mathrm{ij}}, \mathrm{c}_{\mathrm{kj}}\right)=$ Jarak Euclidian Distance antara pengamatan ke-i variabel ke-j ke pusat cluster ke-k pada variabel ke$\mathrm{j}$,

$\mathrm{x}_{\mathrm{ij}}=$ objek pada pengamatan ke-i pada variabel ke-j,

$\mathrm{c}_{\mathrm{kj}}=$ pusat kelompok ke-k pada variabel ke-j,

$\mathrm{p}=$ banyaknya variabel yang diamati,

$\mathrm{n}=$ banyak pengamatan yang diamati.

3. Pilih secara acak objek pada masing-masing cluster sebagai kandidat medoid baru.

4. Hitung jarak setiap objek yang berada pada masing-masing cluster dengan kandidat medoids baru dengan menggunakan rumus Euclidian Distance diatas .

5. Hitung total simpangan (S) dengan menghitung nilai total distance baru - total distance lama. Jika $\mathrm{S}<0$, maka tukar objek dengan data cluster untuk membentuk sekumpulan k objek baru sebagai medoids.

6. Ulangi langkah 3 sampai 5 hingga tidak terjadi perubahan medoids, sehingga didapatkan cluster beserta anggota cluster masing-masing.

\subsection{Teknik Pengumpulan Data}

Penelitian ini menggunakan teknik data sekunder, yaitu data yang didapatkan tidak secara langsung dari objek atau subjek penelitian. Data penelitian ini dihasilkan melalui situs resmi Departemen Kesehatan dengan alamat url https://www.depkes.go.id/_untuk memperoleh data asli. Data penelitian ini menggunakan data kuantitatif, yaitu data yang berbentuk angka pasti yang merupakan data kasus diare ditangani menurut provinsi pada tahun 2017.

\section{ANALISA DAN PEMBAHASAN}

\subsection{Proses Perhitungan Algoritma K-Medoids}

Pada tahap ini adalah proses perhitungan manual dengan menggunakan rumus metode K-Medoids Clustering. Berikut adalah langkah-langkah penyelesaian yang dilakukan penulis dalam mengelompokkan jumlah penanganan kasus diare di Indosesia pada tahun 2017 yang diperoleh dari situs Departemen Kesehatan menggunakan algoritma $K$ Medoids.

1. Menetapkan nilai $\mathrm{k}$ jumlah cluster data sebanyak 2 cluster $(\mathrm{k}=2)$.

2. Menetukan nilai centroid awal yang ditentukan secara random berdasarkan nilai variabel data yang di cluster sebanyak $\mathrm{k}$, seperti pada tabel 1 seperti berikut.

Tabel 1. Medoids

\begin{tabular}{ccccc}
\hline Nama & Provinsi & Perkiraan Diare Di Fasilitas Kesehatan & Diare Ditangani & \% Diare Ditangani \\
\hline C1 & Bali & 114.656 & 60179 & 52,5 \\
C2 & Jambi & 94.905 & 63.194 & 66,6 \\
\hline
\end{tabular}


3. Menempatkan objek-objek non medoids ke dalam cluster yang paling dekat dengan medoids berdasarkan jarak Euclidean. Berikut adalah perhitungan jarak pada data penanganan kasus diare :

$$
\begin{aligned}
& d_{\text {Aceh }, C 1}=\sqrt{(140.116-114.656)^{2}+(83.914-60.179)^{2}+(59,9-52,5)^{2}}=34807,49 \\
& d_{\text {Aceh }, C 2}=\sqrt{(140.116-94.905)^{2}+(83.914-63.194)^{2}+(59,9-66,6)^{2}}=49732,81 \\
& d_{\text {Sumut }, C 1}=\sqrt{(385.078-114.656)^{2}+(99.426-60.179)^{2}+(25,8-52,5)^{2}}=273225,16 \\
& d_{\text {Sumut }, C 2}=\sqrt{(385.078-94.905)^{2}+(99.426-63.194)^{2}+(25,8-66,6)^{2}}=292426,28 \\
& d_{\text {Sumbar }, C 1}=\sqrt{(143.680-114.656)^{2}+(106.847-60.179)^{2}+(74,4-52,5)^{2}}=54957,21 \\
& d_{\text {Sumbar }, C 2}=\sqrt{(143.680-94.905)^{2}+(106.847-63.194)^{2}+(74,4-66,6)^{2}}=65456,74 \\
& d_{\text {Riau }, C 1}=\sqrt{(179.764-114.656)^{2}+(137.813-60.179)^{2}+(76,7-52,5)^{2}}=101321,71 \\
& d_{\text {Riau }, C 2}=\sqrt{(179.764-94.905)^{2}+(137.813-63.194)^{2}+(76,7-66,6)^{2}}=113000,2 \\
& d_{\text {Jambi,C1}}=\sqrt{(94.905-114.656)^{2}+(63.194-60.179)^{2}+(66,6-52,5)^{2}}=19979,80 \\
& d_{\text {Jambi,C2}}=\sqrt{(94.905-94.905)^{2}+(63.194-63.194)^{2}+(66,6-66,6)^{2}}=0
\end{aligned}
$$

\begin{tabular}{|c|c|c|c|c|c|}
\hline \multirow{2}{*}{ No } & \multirow{2}{*}{ Data ke-i } & \multicolumn{2}{|c|}{ Jarak Ke Medoids } & \multirow{2}{*}{ Terdekat } & \multirow{2}{*}{$\begin{array}{c}\text { Cluster } \\
\text { Yang Diikuti }\end{array}$} \\
\hline & & $\mathrm{C} 1$ & $\mathrm{C} 2$ & & \\
\hline 1. & Aceh & 34807,4975 & 49732,816 & 34807,5 & 1 \\
\hline 2. & Sumatera Utara & 273255,166 & 292426,28 & 273255,2 & 1 \\
\hline 3. & Sumatera Barat & 54957,2132 & 65456,742 & 54957,21 & 1 \\
\hline 4. & Riau & 101321,716 & 113000,2 & 101321,7 & 1 \\
\hline 5. & Jambi & 19979,8004 & 0 & 0 & 2 \\
\hline 6. & Sumatera Selatan & 159367,427 & 171410,76 & 159367,4 & 1 \\
\hline 7. & Bengkulu & 75791,786 & 62742,104 & 62742,1 & 2 \\
\hline 8. & Lampung & 136927,247 & 151532,13 & 136927,2 & 1 \\
\hline 9. & Kepulauan Bangka Belitung & 87025,0417 & 72283,363 & 72283,36 & 2 \\
\hline 10. & Kepulauan Riau & 67980,115 & 54057,821 & 54057,82 & 2 \\
\hline 11. & Dki Jakarta & 251980,049 & 263215,94 & 251980 & 1 \\
\hline 12. & Jawa Barat & 1469699,45 & 1483865,8 & 1469699 & 1 \\
\hline 13. & Jawa Tengah & 885032,56 & 901953,03 & 885032,6 & 1 \\
\hline 14. & Yogyakarta & 23158,4724 & 23112,58 & 23112,58 & 2 \\
\hline 15. & Jawa Timur & 1091781,02 & 1107465,6 & 1091781 & 1 \\
\hline 16. & Banten & 281834,147 & 295847,79 & 281834,1 & 1 \\
\hline 17. & Bali & 0 & 19979,8 & 0 & 1 \\
\hline 18. & Nusa Tenggara Barat & 116762,281 & 118719,58 & 116762,3 & 1 \\
\hline 19. & Nusa Tenggara Timur & 31431,9795 & 50814,589 & 31431,98 & 1 \\
\hline 20. & Kalimantan Barat & 22231,0382 & 39381,253 & 22231,04 & 1 \\
\hline 21. & Kalimantan Tengah & 48962,9409 & 34229,213 & 34229,21 & 2 \\
\hline 22. & Kalimantan Selatan & 7407,76891 & 16711,502 & 7407,769 & 1 \\
\hline 23. & Kalimantan Timur & 26184,393 & 15971,606 & 15971,61 & 2 \\
\hline 24. & Kalimantan Utara & 105527,928 & 89484,816 & 89484,82 & 2 \\
\hline 25 . & Sulawesi Utara & 65797,1164 & 55625,217 & 55625,22 & 2 \\
\hline 26. & Sulawesi Tengah & 34668,6694 & 15870,61 & 15870,61 & 2 \\
\hline 27. & Sulawesi Selatan & 155952,62 & 169879,93 & 155952,6 & 1 \\
\hline 28. & Sulawesi Tenggara & 46250,4652 & 35122,464 & 35122,46 & 2 \\
\hline 29. & Gorontalo & 94891,3563 & 79977,728 & 79977,73 & 2 \\
\hline 30. & Sulawesi Barat & 83432,1282 & 66461,983 & 66461,98 & 2 \\
\hline 31. & Maluku & 79448,0882 & 65536,342 & 65536,34 & 2 \\
\hline 32. & Maluku Utara & 96266,4859 & 82043,672 & 82043,67 & 2 \\
\hline 33. & Papua Barat & 44182,1208 & 38786,126 & 38786,13 & 2 \\
\hline \multirow[t]{3}{*}{34.} & Papua & 107975,925 & 93995,596 & 93995,6 & 2 \\
\hline & Jumlah & 6182272,01 & 6196694,9 & & \\
\hline & Total Cost & 12378966,91 & & & \\
\hline
\end{tabular}

Hasil selengkapnya perhitungan jarak ke setiap medoids, dapat dilihat pada tabel 2 berikut:

Tabel 2. Hasil Perhitungan Jarak Ke Setiap Medoids

4. Menentukan objek yang telah ditentukan sebagai non medoids sebagai berikut: 
Tabel 3. Non Medoids

\begin{tabular}{ccccc}
\hline Nama & Provinsi & $\begin{array}{c}\text { Perkiraan Diare Di } \\
\text { Fasilitas } \\
\text { Kesehatan }\end{array}$ & Diare Ditangani & \% Diare Ditangani \\
& & 24.094 & 1.380 & 5,7 \\
A1 & Papua & 1.060 .910 & 604.779 & 5,7 \\
A2 & Jawa Timur & & & \\
\hline
\end{tabular}

5. Menempatkan kembali objek-objek non medoids ke dalam cluster yang paling dekat dengan medoids berdasarkan jarak Euclidean. Berikut adalah perhitungan jarak pada data penanganan kasus diare :

$d_{\text {Ace }, A 1}=\sqrt{(140.116-24.094)^{2}+(83.914-1.380)^{2}+(59,9-5,7)^{2}}=145320,80$

$d_{\text {Aceh,A2 }}=\sqrt{(140.116-1.060 .910)^{2}+(83.914-604.779)^{2}+(59,9-5,7)^{2}}=1057904,50$

$d_{\text {Sumut }, A 1}=\sqrt{(385.078-24.094)^{2}+(99.426-1.380)^{2}+(25,8-5,7)^{2}}=374466,12$

$d_{\text {Sumut }, A 2}=\sqrt{(385.078-1.060 .910)^{2}+(99.426-604.779)^{2}+(25,8-5,7)^{2}}=843878,27$

$d_{\text {Sumbar }, A 1}=\sqrt{(143.680-24.094)^{2}+(106.847-1.380)^{2}+(74,4-5,7)^{2}}=164169,05$

$d_{\text {Sumbar,A2 }}=\sqrt{(143.680-1.060 .910)^{2}+(106.847-604.779)^{2}+(74,4-5,7)^{2}}=1043670,04$

$d_{\text {Riau }, A 1}=\sqrt{(179.764-24.094)^{2}+(137.813-1.380)^{2}+(76,7-5,7)^{2}}=212036,44$

$d_{\text {Riau }, A 2}=\sqrt{(179.764-1.060 .910)^{2}+(137.813-604.779)^{2}+(76,7-5,7)^{2}}=997233,93$

$d_{\text {Jambi,A1 }}=\sqrt{(94,905-24.094)^{2}+(63,194-1.380)^{2}+(66,6-5,7)^{2}}=97704,38$

$d_{\text {Jambi,A2 }}=\sqrt{(94,905-1.060 .910)^{2}+(63,194-604.779)^{2}+(66,6-5,7)^{2}}=1107465,56$

Hasil perhitungan jarak ke setiap non medoids baru, dapat dilihat pada tabel 4 berikut :

Tabel 4. Hasil Perhitungan Jarak Ke Setiap Non Medoids Baru

\begin{tabular}{|c|c|c|c|c|c|}
\hline \multirow[t]{2}{*}{ No. } & \multirow[t]{2}{*}{ Data ke-i } & \multicolumn{2}{|c|}{ Jarak Ke Medoids } & \multirow[t]{2}{*}{ Terdekat } & \multirow{2}{*}{$\begin{array}{c}\text { Cluster } \\
\text { Yang Diikuti }\end{array}$} \\
\hline & & $\mathrm{C} 1$ & $\mathrm{C} 2$ & & \\
\hline 1. & Aceh & 145320,805 & 1057904,505 & 145320,805 & 1 \\
\hline 2. & Sumatera Utara & 374466,126 & 843878,2775 & 374466,126 & 1 \\
\hline 3. & Sumatera Barat & 164169,053 & 1043670,041 & 164169,053 & 1 \\
\hline 4. & Riau & 212036,441 & 997233,9362 & 212036,441 & 1 \\
\hline 5. & Jambi & 97704,3861 & 1107465,564 & 97704,3861 & 1 \\
\hline 6. & Sumatera Selatan & 270806,965 & 940669,1752 & 270806,965 & 1 \\
\hline 7. & Bengkulu & 33016,5156 & 1167342,553 & 33016,5156 & 1 \\
\hline 8. & Lampung & 248121,277 & 956091,4356 & 248121,277 & 1 \\
\hline 9. & Kepulauan Bangka Belitung & 23582,5711 & 1178798,229 & 23582,5711 & 1 \\
\hline 10. & Kepulauan Riau & 41696,6809 & 1159754,461 & 41696,6809 & 1 \\
\hline 11. & DKI Jakarta & 364017,577 & 857531,4418 & 364017,577 & 1 \\
\hline 12. & Jawa Barat & 1581876,12 & 404422,4701 & 404422,47 & 2 \\
\hline 13. & Jawa Tengah & 993320,748 & 231956,9087 & 231956,909 & 2 \\
\hline 14. & Yogyakarta & 88260,9899 & 1112694,17 & 88260,9899 & 1 \\
\hline 15. & Jawa Timur & 1202247,37 & 51,3 & 51,3 & 2 \\
\hline 16. & Banten & 393595,231 & 813907,2244 & 393595,231 & 1 \\
\hline 17. & Bali & 110166,155 & 1091781,02 & 110166,155 & 1 \\
\hline 18. & Nusa Tenggara Barat & 221406,988 & 1021729,383 & 221406,988 & 1 \\
\hline 19. & Nusa Tenggara Timur & 127516,541 & 1074769,98 & 127516,541 & 1 \\
\hline 20. & Kalimantan Barat & 132577,68 & 1069596,218 & 132577,68 & 1 \\
\hline 21. & Kalimantan Tengah & 62361,3145 & 1140582,862 & 62361,3145 & 1 \\
\hline 22. & Kalimantan Selatan & 111881,891 & 1091494,75 & 111881,891 & 1 \\
\hline 23. & Kalimantan Timur & 112040,093 & 1098349,955 & 112040,093 & 1 \\
\hline 24. & Kalimantan Utara & 22636,5131 & 1196884,418 & 22636,5131 & 1 \\
\hline 25 . & Sulawesi Utara & 44920,0783 & 1155994,574 & 44920,0783 & 1 \\
\hline 26. & Sulawesi Tengah & 83647,9487 & 1123174,171 & 83647,9487 & 1 \\
\hline 27. & Sulawesi Selatan & 267384,886 & 938470,2407 & 267384,886 & 1 \\
\hline 28. & Sulawesi Tenggara & 63208,9005 & 1137746,911 & 63208,9005 & 1 \\
\hline 29. & Gorontalo & 16586,0757 & 1186657,064 & 16586,0757 & 1 \\
\hline 30. & Sulawesi Barat & 40522,5808 & 1173896,339 & 40522,5808 & 1 \\
\hline 31. & Maluku & 29706,1736 & 1171190,907 & 29706,1736 & 1 \\
\hline 32. & Maluku Utara & 12559,7783 & 1188010,133 & 12559,7783 & 1 \\
\hline
\end{tabular}




\begin{tabular}{|c|c|c|c|c|c|}
\hline \multirow{4}{*}{$\begin{array}{l}33 . \\
34 .\end{array}$} & Papua Barat & 68533,9812 & 1132659,309 & 68533,9812 & 1 \\
\hline & Papua & 0 & 1199615,676 & 0 & 1 \\
\hline & Jumlah & 7761896,43 & 34065975,6 & & \\
\hline & Total Cost & 41827872,03 & & & \\
\hline
\end{tabular}

6. Menghitung nilai $S$ dengan persamaan 1. sebagai berikut:

$S=$ total cost baru - total cost lama

Dengan : $S=$ Selisih

Total cost baru $=$ total cost non medoids

Total cost lama = total cost untuk medoids

Sehingga diperoleh:

$S=41827872,03-12378966,91=29448905,12$

7. Karena nilai $\mathrm{S}>0$ maka proses pengklasteran dihentikan. Sehingga diperoleh anggota tiap cluster.

\subsection{Hasil Clustering Rapidminer}

Pada gambar dibawah ini merupakan proses menghubungkan read excel dengan operator $k$-medoids dan output yang akan di eksekusi.

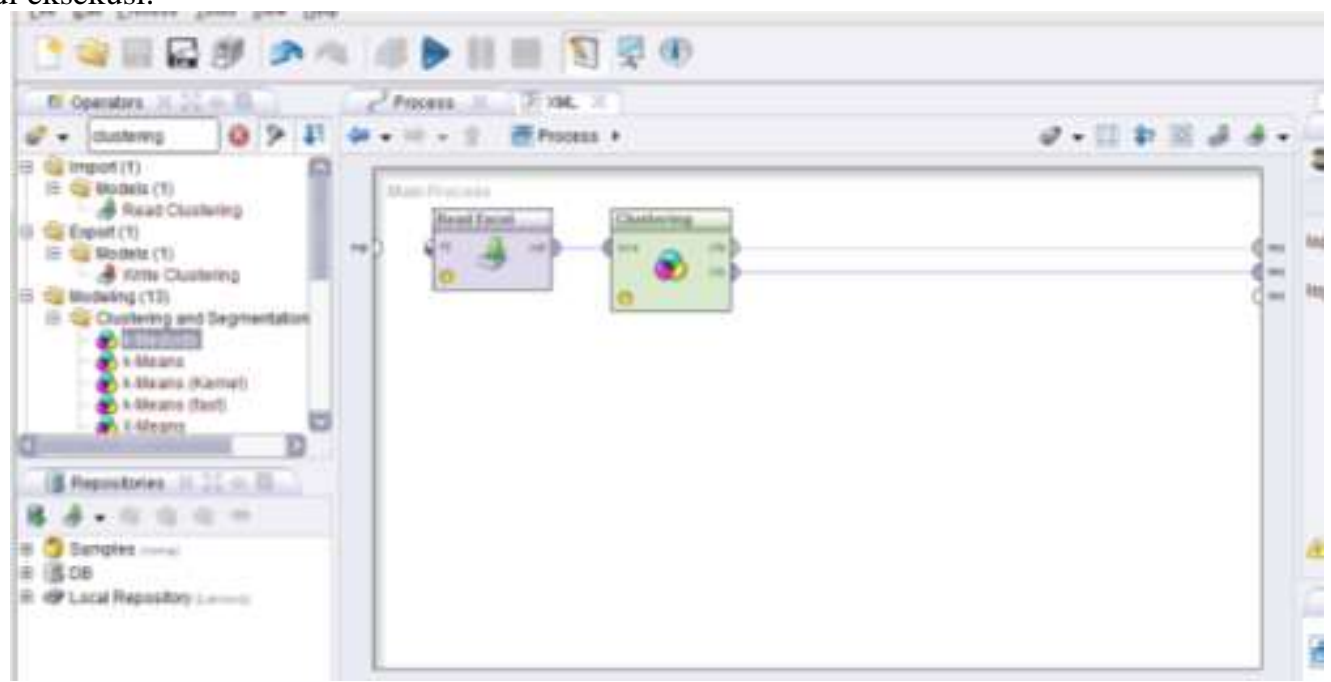

Gambar 1. Menghubungkan Read Excel dengan Operator k-medoids

Selanjutnya klik tool run yang berbentuk segitiga kesamping berwarna biru. Pada saat tool run diklik muncul hasil cluster seperti gambar dibawah.

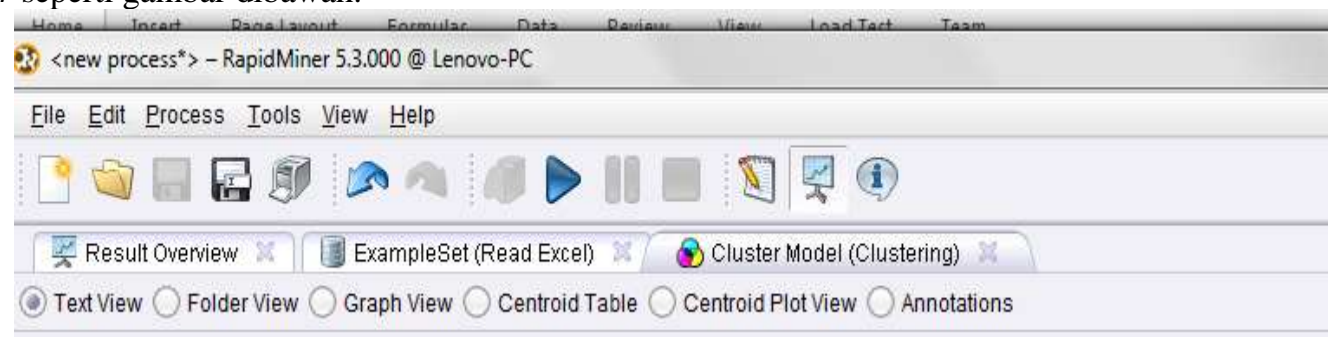

\section{Cluster Model}

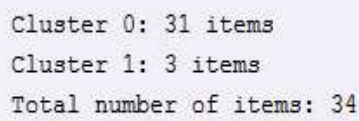

Gambar 2. Data Hasil Clustering menggunakan K-Medoids

Berdasarkan gambar diatas menjelaskan bahwa terdapat 2 cluster yang dimulai dari cluster 0 dan cluster 1. Cluster 0 merupakan cluster rendah( $\mathrm{C} 1$ pada perhitungan manual) dan cluster 1 merupakan cluster tinggi (C2 pada perhitungan manual). 


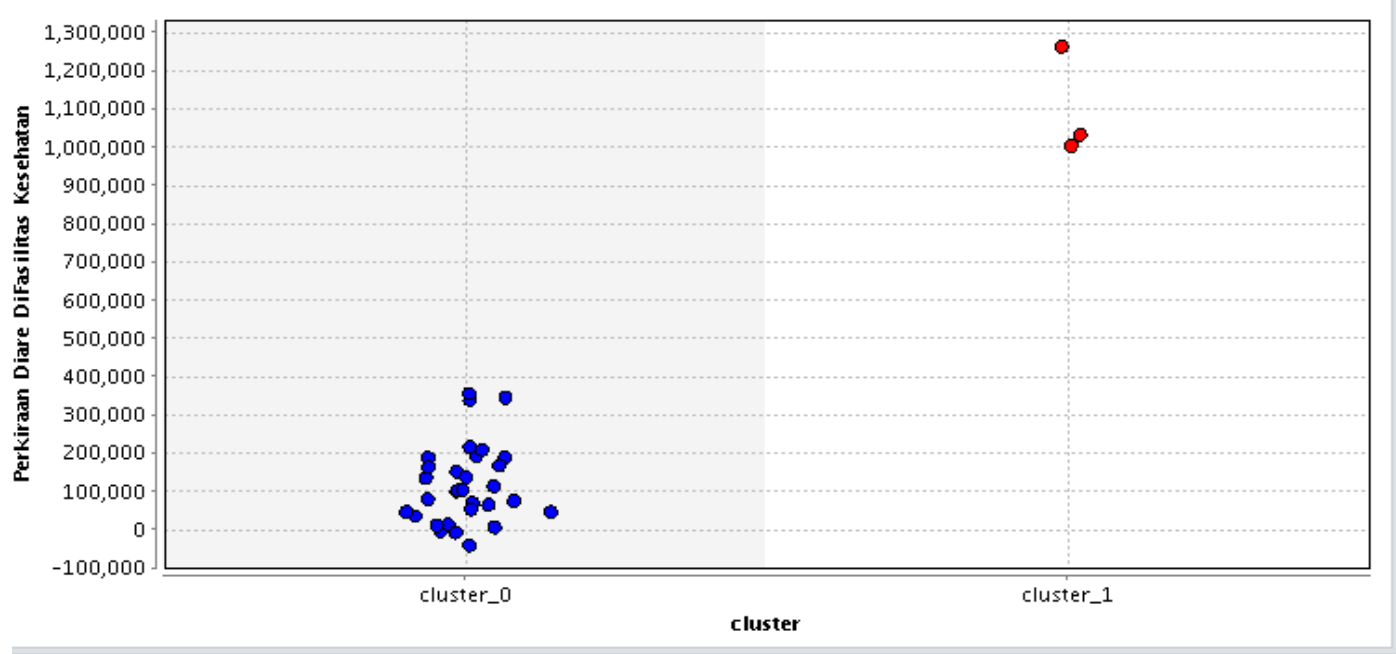

Gambar 3. Grafik Clustering

\section{KESIMPULAN}

Penerapan Data Mining menggunakan algoritma $K$-Medoids untuk mengelompokkan penanganan kasus diare menurut provinsi dengan data uji sebanyak 34 provinsi dengan menggunakan dua cluster. cluster 1 (nilai rendah) sebanyak 31, cluster 2 (nilai tinggi) sebanyak 3. Hasil yang diperoleh dalam mengkluster jumlah penanganan kasus diare di Indonesia pada tahun 2017 menggunakan metode $K$-Medoids adalah jumlah provinsi yang termasuk cluster 1 (rendah) berjumlah 31 provinsi yaitu Aceh, Sumatera Utara, Sumatera Barat, Riau, Jambi, Sumatera Selatan, Bengkulu, Lampung, Kepulauan Bangka Belitung, Kepulauan Riau, DKI Jakarta, DI Yogyakarta, Banten, Bali, Nusa Tenggara Barat, Nusa Tenggara Timur, Kalimantan Barat, Kalimantan Tengah, Kalimantan Selatan, Kalimantan Timur, Kalimantan Utara, Sulawesi Utara, Sulawesi Tengah, Sulawesi Selatan, Sulawesi Tenggara, Gorontalo, Sulawesi Barat, Maluku, Maluku Utara, Papua Barat dan Papua. Sedangkan provinsi yang termasuk cluster 2 (tinggi) 3 provinsi yaitu Jawa Barat, Jawa Tengah dan Jawa Timur. Hasil tersebut sama dengan hasil yang telah di implementasikan ke dalam software rapidminer versi 5.3.

Dari hasil perhitungan $K$-Medoids pada bab sebelumnya, Cluster 2 (C2) merupakan jumlah penanganan kasus diare yang termasuk Cluster tertinggi. Dari hasil yang diperoleh, posisi Cluster tertinggi dapat menjadi masukan kepada pihak pemerintah indonesia yang terkait agar pihak pemerintah lebih memperhatikan provinsi di indonesia yang mendapatkan cluster tertinggi untuk memberikan penanganan khusus dalam kasus diare.

\section{REFERENCES}

[1] D. Defiyanti Sofi, Optimalisasi K-Medoid Dalam Pengklasteran Mahasiswa Pelamar Beasiswa Dengan Cubic Clustering Criterion, Vol. 3, No. 1, Pp. 211-218, 2017.

[2] Y. H. Chrisnanto And G. Abdillah, Penerapan Algoritma Partitioning Around Medoids (PAM) Clustering Untuk Melihat Gambaran Umum Kemampuan, Vol. 2015, No. Sentika, Pp. 444-448, 2015.

[3] A. E. Pramadhani And T. Setiadi, Penerapan Data Mining Untuk Klasifikasi Prediksi Penyakit Ispa (Infeksi Saluran Pernapasan Akut ) Dengan Algoritma Decision Tree ( Id3 ), Vol. 2, 2014.

[4] R. R. Putra And C. Wadisman, No Title, Vol. 1, No. 1, Pp. 72-77, 2018.

[5] D. F. Pramesti, M. T. Furqon, And C. Dewi, Implementasi Metode K-Medoids Clustering Untuk Pengelompokan Data Potensi Kebakaran Hutan / Lahan Berdasarkan Persebaran Titik Panas ( Hotspot ), J. Pengemb. Teknol. Inf. Dan Ilmu Komput., Vol. 1, No. 9, 2017.

[6] B. D. Satoto, B. K. Khotimah, And Iswati, Pendidikan Menggunakan Partition Around Medoids Dan,Vol. 1, No. 1, Pp. 17$24,2015$. 